\title{
NEW RECORDS FOR THE CHILEAN ALTIPLANO CRYPTOGAMIC FLORA
}

\section{NUEVOS REGISTROS PARA LA FLORA CRIPTOGAMICA DELALTIPLANO CHILENO}

\author{
Juan Larraín ${ }^{1} \&$ Reinaldo Vargas ${ }^{1,2}$ \\ ${ }^{1}$ Departamento de Botánica, Universidad de Concepción, Casilla 160-C, Concepción, Chile. ${ }^{2}$ Departamento de \\ Biología, Universidad Metropolitana de Ciencias de la Educación, Casilla 147, Santiago, Chile. \\ juanlarrain@udec.cl

\section{RESUMEN}

Son reportadas dos nuevas criptógamas para el altiplano de la Provincia de Parinacota en el norte de Chile: el líquen Caloplaca fragillima Poelt, conocido previamente en Chile sólo de la localidad tipo en la provincia de Valparaíso, y el musgo Grimmia trinervis R.S.Williams, reportado anteriormente como endémico del altiplano de Perú y Bolivia.

During the preparation of a revision of the genus Caloplaca (Teloschistaceae, Teloschistales) in Chile being undertaken by the second author, we found a very interesting collection of a fragile lichen that was growing tightly associated with a tiny moss species. Microscopic observations confirmed the identities of these species as Caloplaca fragillima Poelt and Grimmia trinervis R.S.Williams. Neither of these cryptogamic species was known for the high plateaus (altiplano) of northern Chile, the former reported for Valparaíso Province in central Chile (Poelt \& Pelleter 1984), and the latter reported as an endemic of the Andean altiplano of Peru (Ancash, Arequipa, La Libertad, Puno) and Bolivia (Cochabamba, La Paz, Oruro, Potosi) (Williams 1903, Deguchi 1987, Hastings 1996, Muñoz 1999, Muñoz \& Pando 2000).

The lichen genus Caloplaca Th.Fr. comprises a large diversity of almost 1,100 species worldwide, and can be partly divided in more or less distinctive species groups (Ozenda \& Clauzade 1970, Kärnefelt 1989, Gaya et al. 2008) ranging from crustose to fruticose thalli. In Chile, $c a .50$ species are known so far (Galloway \& Quilhot 1998, Pereira \& Torres 2005), including those occurring in the Chilean Antarctic Territory.

Caloplaca fragillima is an endemic species of Chile that has a fruticose to subfruticose thallus (Fig.
$1 \mathrm{~A})$, usually erect but sometimes applicated or bent, without prothallus. The thallus is composed by fragile erect and richly branched lobes that can be partly divided forming small crenulated lobules at their apices; the lobes are rounded, terete or irregular in cross section, 2-3 mm long and (0.1-)0.2-0.5 mm wide; the surface of the lobes is light to deep orange, smooth, without pruina nor pseudocyphellae, strongly reacting with a $10 \%$ solution of $\mathrm{KOH}$ in the upper portions, dark to whitish gray and not reacting with $\mathrm{KOH}$ in the lower portions. The cortex is cellular or formed by prosoplectenchymatous hyphae anticlinally oriented (Fig. 1 B), and the medulla is formed by a very compacted prosoplectenchyma of interwoven hyphae, sometimes with highly packed groups of hyphae with the algae arranged in groups. In the material observed no sexual or asexual reproductive structures could be seen. Poelt \& Pelleter (1984) suggested that this species seems to propagate by thallus fragmentations.

Caloplaca fragillima was only known from the type material collected by Poelt near Quintero in Valparaíso Province, growing in crevices on seashore rocks (Poelt \& Pelleter 1984). This is the first report of the species since the original description, and the first in the high plateaus of northern Chile. 
Caloplaca fragillima is distinguished from other Caloplaca species from Chile by the small and fragile fruticose to subfruticose thallus of $c a .3 \mathrm{~mm}$ tall, the prosoplectenchymatous cortex of anticlinally oriented hyphae and the absence of reproductive structures. The species is closely related to the subfruticose species Caloplaca coralloides (Tuck.) Hulting, an endemic species of the coastal areas of western North America, with the most distinctive difference being the larger lobes and the presence of well developed apothecia in the latter. However, the scant material of $C$. fragillima can not provide enough clues on this matter (Kärnefelt 1998). More field studies must be carried out to resolve this issue.
The moss genus Grimmia (sensu lato) contains about 80 species worldwide, with greater diversity in the temperate and cold regions (Muñoz \& Pando 2000, Greven 2003). In Chile 12 species have been reported (He 1998, Muñoz 1999, Cano 2003), growing along the Andes from the border with Peru and Bolivia to Cape Horn.

Grimmia trinervis was described by Williams (1903) based on one specimen that he collected in Juliaca, Peru, at 3,780 m a.s.1., on dry sandstone. He placed this new species in an also new subgenus, Tricostatae R.S.Williams. Until Deguchi's (1987) treatment, the species remained unstudied for many years, and its generic placement has been troublesome, starting with its placement in

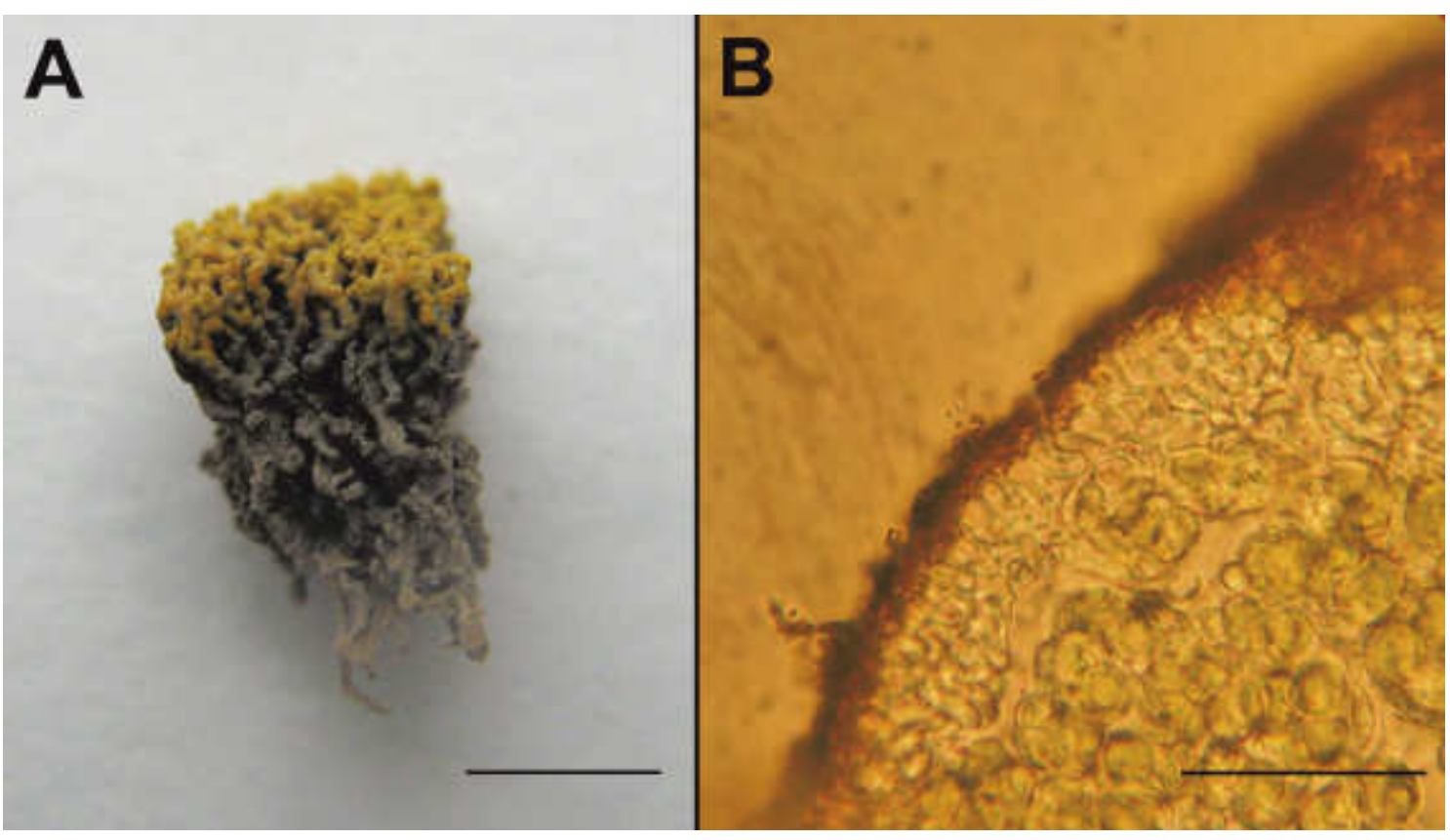

FIgure 1. Caloplaca fragillima. A. Habit of the thallus. B. Detail of the cortex of the lobes showing the cellular to prosoplectenchymatous hyphae (Scale: $\mathrm{A}=1 \mathrm{~mm} ; \mathrm{B}=50 \mu \mathrm{m})$.

Figura 1. Caloplaca fragillima. A. Hábito del talo. B. Detalle de la corteza de los lóbulos mostrando las hifas de celulares a prosoplectenquimáticas (Escala: $\mathrm{A}=1 \mathrm{~mm} ; \mathrm{B}=50 \mu \mathrm{m}$ ). 
Coscinodon by Brotherus (in Herzog 1916). Since then two trends have arisen about the phylogenetic relationships of this species: one putting emphasis on gametophytic traits, which definitely groups $G$. trinervis with Coscinodon species (Brotherus in Herzog 1916, Churchill 1981, Hastings 1996), and the other one putting emphasis on sporophytic traits, which groups $G$. trinervis with species of Grimmia subg. Grimmia (Deguchi 1987, Muñoz 1999). Recent molecular studies suggest a third trend, which would nest G. trinervis with species of Grimmia subg. Orthogrimmia, with which it shares few gametophytic morphological characters (Hernández-Maqueda et al. 2007, 2008). Due to the complexity of the phylogenetic relations of this taxon, we prefer to treat it under Grimmia in a broad sense. Complete descriptions of this taxon can be found in Williams (1903), Deguchi (1987), Hastings (1996, as Coscinodon trinervis), and Muñoz (1999), the latter three works also containing illustrations.

Although the specimen studied is in sterile condition, and some authors argue that is difficult to determine with confidence sterile material of this species, because possible confusion with Coscinodon species (Hastings 1996, Muñoz 1999), the strong leaf plications (Fig. 2 A-B) reaching the base of the leaf (Fig. 2 C), the small size of the leaves (always smaller than $0.9 \mathrm{~mm}$, measured without hairpoint, Fig. 2 C), and the locality and habitat where it was collected, make us quite sure about its taxonomic identity. Fertile plants are needed for corroborating its identity.

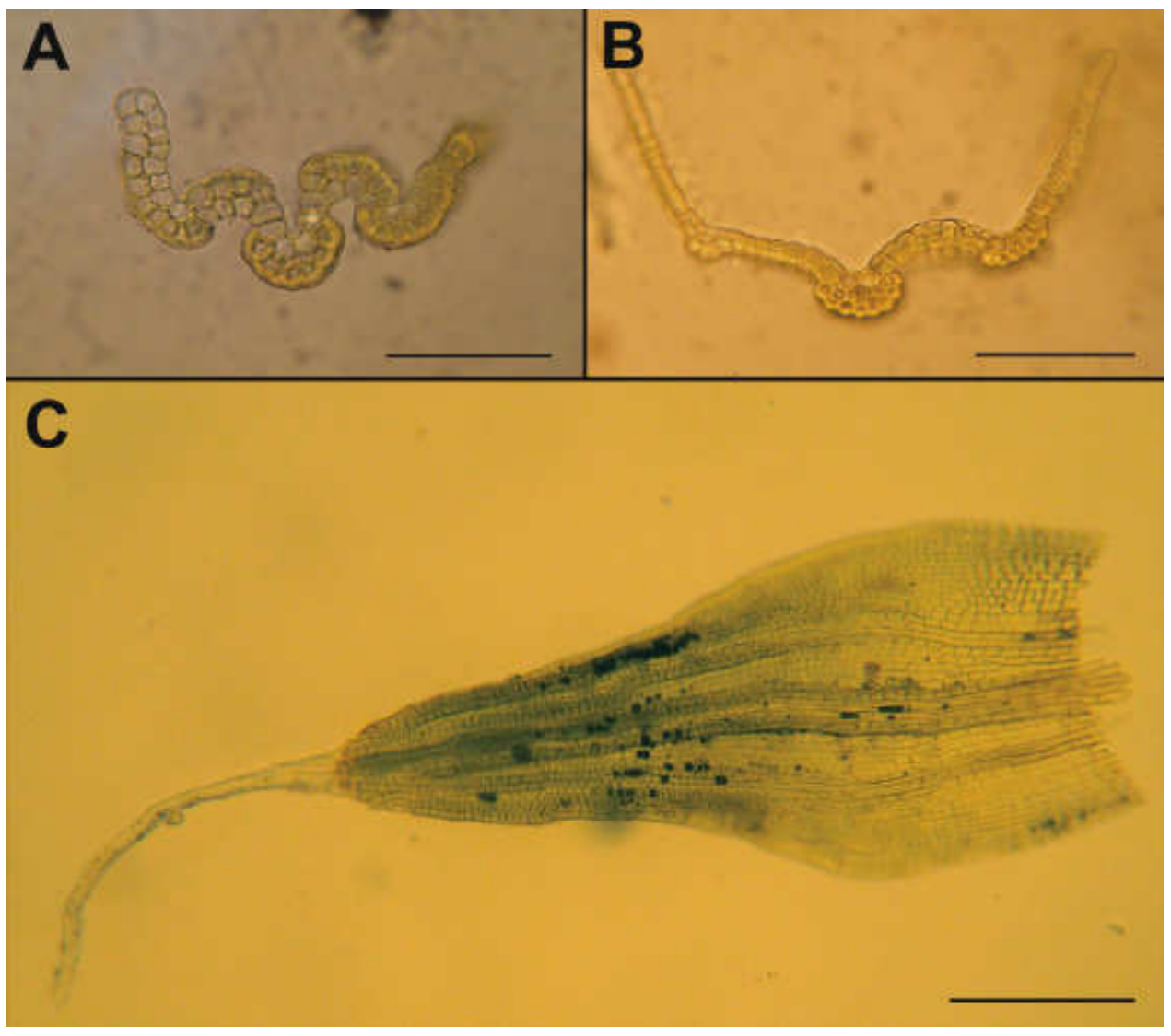

FiguRE 2. Grimmia trinervis. A. Leaf cross section at midleaf; B. Leaf cross section below midleaf; C. Leaf (Scale: A=75 $\mu \mathrm{m} ; \mathrm{B}=100 \mu \mathrm{m} ; \mathrm{C}=200 \mu \mathrm{m})$.

FiguRA 2. Grimmia trinervis. A. Sección transversal de la parte media de la hoja; B. Sección transversal de la parte proximal de la hoja; C. Hoja (Escala: A= $75 \mu \mathrm{m} ; \mathrm{B}=100 \mu \mathrm{m} ; \mathrm{C}=200 \mu \mathrm{m}$ ). 
Gayana Bot. 66(1), 2009

The collection examined is labeled as growing on rocks, although the herbarium sample was clearly immersed in a conspicuous matrix of sand, which could have been lying over the rock or, more probably, in a rock crevice. This agrees with the few ecological data we could find about G. trinervis (Williams 1903, Hastings 1996, Muñoz 1999) which reported the species as growing on sandstone, basalt cliffs and dry rock outcrops. The species has been recorded as growing between 3,780 to $5,100 \mathrm{~m}$, so this new record corresponds to the lower altitude in which the species has been found $(3,350 \mathrm{~m})$.

Studied MATERIAL: CHILE, Región de Arica y Parinacota (XV), Prov. Parinacota, entre Zapahuira y Putre, sobre roca; $3.350 \mathrm{~m}$; $18^{\circ} 17^{\prime} \mathrm{S}, 6^{\circ} 35^{\prime} \mathrm{W}$. 13-IX-1996. Galloway, Rubio \& Quilhot s/n (UV 100895, CONC).

\section{ACKNOWLEDGEMENTS}

We thank Professor Wanda Quilhot, curator at UV, for the loan of the studied specimen, Jesús Muñoz for checking the identity of the moss species, and Camille Truong for her suggestions and comments on the manuscript.

\section{BIBLIOGRAPHY}

CANO, M.J. 2003. New records and range extension of some mosses in tropical areas of Chile. Tropical Bryology 24: $15-20$.

ChuRChILl, S.P. 1981. A phylogenetic analysis, classification and synopsis of the genera of the Grimmiaceae (Musci). In: V.A. Funck \& D.R. Brooks (eds.), Advances in Cladistics. Proceedings of the first meeting of the Willi Hennig Society. pp. 127-144. The New York Botanical Garden.

Deguchi, H. 1987. Studies on some Peruvian species of Grimmiaceae (Musci, Bryophyta). In: H. Inoue (ed.), Studies on Cryptogams in Southern Peru. pp. 19-74. Kensei-Sha, Tokyo.

Galloway, D.J. \& W. Quilhot. 1998. Checklist of Chilean lichen-forming and lichenicolous fungi. Gayana Botánica 55: 111-185.

Gaya, E., P. Navarro-Rosinés, X. Llimona, N. Hlandun \& F. LutZonI. 2008. Phylogenetic reassessment of the Teloschistaceae (lichen-forming Ascomycota, Lecanoromycetes). Mycological Research 112: 528-546

Greven, H.C. 2003. Grimmias of the world. Backhuys Publishers, Leiden. 247 pp.

Hastings, R. 1996. The genus Coscinodon (Bryopsida, Grimmiaceae) in South America, including a new species. The Bryologist 99: 418-427.

HE, S. 1998. A checklist of the mosses of Chile. Journal of the Hattori Botanical Laboratory 85: 103-189.

Hernández-Maqueda, R., J. MuÑoz \& O. Werner. 2007. Incongruencia entre señal morfológica y molecular: una nueva propuesta sistemática para el complejo Grimmiaceae-Ptychomitriaceae (Bryophyta). Dissertation. Universidad Autónoma de Madrid. $186 \mathrm{pp}$.

Hernández-Maqueda, R., D. Quandt, O. Werner \& J. MuÑOz. 2008. Phylogeny and classification of the Grimmiaceae/Ptychomitriaceae complex (Bryophyta) inferred from cpDNA. Molecular Phylogenetics and Evolution 46: 863-877.

Herzog, T. 1916. Die Bryophyten meiner zweiten Reise durch Bolivia. Bibliotheca Botanica 87: 1-168.

KÄRNEFELT, E.I. 1989. Morphology and phylogeny in the Teloschistales. Cryptogamic Botany 1: 147-203.

KäRNEFELT, E.I. 1998. Problems related to the maritime lobate and subfruticose species of Caloplaca. Folia Cryptogamica Estonica 32: 27-35.

Muñoz, J. 1999. A revision of Grimmia (Musci, Grimmiaceae) in the Americas. 1: Latin America. Annals of the Missouri Botanical Garden 86: 118191

Muñoz, J. \& F. PANDo. 2000. A world synopsis of the genus Grimmia. Monographs in Systematic Botany from the Missouri Botanical Garden 82: 1-113.

Ozenda, P. \& G. Clauzade. 1970. Les Lichens. Étude Biologique et Flore Illustrée. Masson \& Cie. Editeurs, Paris. 801 pp.

Pereira, I. \& W. Torres. 2005. Cinco nuevos registros de líquenes marinos para Chile. Gayana Botánica 62: 20-25.

Poelt, J. \& U. Pelleter. 1984. Zwergstrauchige Arten der Flechtengattung Caloplaca. Plant Systematics and Evolution 148: 51-88.

WiLliams, R.S. 1903. Bolivian Mosses, Part I. Bulletin of the New York Botanical Garden 3: 104-133. 